\title{
Solid Waste Characterization, Fats and Oils in Two Tourist Resorts Cartagena Colombia
}

\author{
Claudia Diaz Mendoza, Juan Carlos Valdelamar, Jhon Jairo Jimenez, Gilma Rosa Avila
}

Fundacion Universitaria Tecnologico Comfenalco Colombia, Cartagena, Colombia.

Email: ing.claudia.diaz@gmail.com, juvaldelamar@gmail.com,jjjimenez1989@hotmail.com,gram0412@hotmail

Received May 26 ${ }^{\text {th }}$, 2013; revised July $3^{\text {rd }}, 2013$; accepted August $5^{\text {th }}, 2013$

Copyright (c) 2013 Claudia Diaz Mendoza et al. This is an open access article distributed under the Creative Commons Attribution License, which permits unrestricted use, distribution, and reproduction in any medium, provided the original work is properly cited.

\begin{abstract}
The objective of the proposed work was collecting samples continuously. Once a month, for a period of two years, it was conducted to determine the types of solid waste generated and deposited in the sand of the tourist beaches, finding that there are predominance waste plastics, cigarette butts and organic debris. Other parameter analyzed was determination of fats and oils in sand whose results indicate that the levels found are above the detection limit. We have come to conclusion that solid waste types commonly arranged in the sand are plastic, and the presence of fats and oils in the sand affects the environmental quality of the beach.
\end{abstract}

Keywords: Waste; Sand; Beaches; Fats; Quality

\section{Introduction}

Evaluating the quality of a beach usually is performed in response to a single or a very restricted set of factors that determine it. Within the framework of an integrated management of the coast, it is of great interest to learn what are the factors that determine the quality of a beach from the point of view of its use as recreational and tourism resource [1].

The quality of the beach among other aspects is related to quality healthcare, quality recreational and ecosystem quality. Within the above indicators are parameters that can be measured directly on the beaches, so as in the study aimed at determinations of the presence of solid waste, waste classification found, most representative day (morning, noon, evening), location and presence of fat and oils sands tourist beaches.

Research in Brazil [2] relates the solid residues with aesthetic conditions, health and environment, which in turn influences the influx of tourists to the beaches. Studies [3] suggest that most of the waste deposites on the sand are made of plastic, which affects the quality of the beach, additional proposed mechanism to reduce this waste, strengthening environmental education for tourists and staff working on the beaches. The results indicate that the predominant waste on the beaches studied are plastic, cigarette butts and organic debris, confirming the data shown in studies by other authors.
As a result of the investigation, it was determined quantitatively the presence of fats and oils in the sand, there was further qualification of solid waste found in the sand of the beaches according to the type of waste and frequency of discovery. This research is of great importance because of the management plans for solid wastes in beaches and the environmental education programs to be developed with users and workers in the beaches, that will be generated in a later stage, from the wastes characterization obtained.

\section{Materials and Methods}

The study was conducted in two tourist beaches in Bocagrande, Cartagena city, into which two sampling stations were established and in Tierra Bomba Island where it was established a station. Sand samples were collected in the morning and in the afternoon, in the period between October 2011 and November 2012, it was assessed the presence of fats and oils (SM 5520-B) and solid waste on the beach sand, qualitative determination was made of solid, using the statistical package Statgraphic ${ }^{\circledR}$ Centurion $\mathrm{XV}$, finding the frequency with which it is presented and type of waste disposal common place, according to zoning and considering the area made $\mathrm{Z} 1$ as the closest to the boardwalk and pathway, Z2 as one area where the tents are located off the $\mathrm{Z} 3$ zone and located near the sea. 


\section{Results and Discussion}

The study was conducted in Bocagrande tourist beach on the island of Tierra Bomba industry Punta Arena, Cartagena, Colombia, the coordinates are given in Table $\mathbf{1}$.

The presence of oils and fats was evaluated according to the standard (NTS-TS 001-2), which says that there should be no obvious stains from grease, oil and oil residues in sand [4]. In Figure 1, as evidenced during the two years of sampling was recorded the presence of oils and fats critical values between $2500-4500 \mathrm{mg} / \mathrm{kg}$ (detection benchmark $500 \mathrm{mg} / \mathrm{kg}$ ), with January being the month when gave the highest levels of fats and oils in both years, also found that the beach that presents higher values in this parameter corresponds to the pump ground island, a phenomenon that can be attributed to motor boat traffic in this area, as well as the influence of water from the channel of the dam, due to currents and winds are brought to the island [5].

The qualification of solid waste is carried out taking into account the presence of nine types of solid waste [6], identified as paper and cardboard, plastics, ordinary glass, organic waste, textiles, inert, wood and metal, it took 21 samples recorded between the months of October 2010 and December 2012, in Figure 2 there is a trend in terms of solid waste units, the predominant sand are cigarette butts and metals. Metals affect the quality in terms of landscape and health indicator, as the predominant metal cans and lids, which can cause injury to users and cut about cigarette butts affect landscape indicator and also as research conducted about $80 \%$ of the cigarettes have filters is cellulose acetate, which concentrate nicotine, tar, arsenic, cadmium, lead, and polyaromatic hydrocarbons, which may adversely affect the environment [7].

Table 1. Locating sampling points.

\begin{tabular}{ccc}
\hline Point & Location & Name of the beach \\
\hline P-1 & $75^{\circ} 33^{\prime} 16.4^{\prime \prime} \mathrm{W}$ & Bocagrande \\
& $10^{\circ} 24^{\prime} 2,4^{\prime \prime} \mathrm{N}$ & \\
$\mathbf{P}-2$ & $75^{\circ} 33^{\prime} 22^{\prime \prime} \mathrm{W}$ & Bocagrande \\
& $10^{\circ} 24^{\prime} 13.4^{\prime \prime} \mathrm{N}$ & \\
$\mathbf{P}-\mathbf{3}$ & $75^{\circ} 33^{\prime} 32.5^{\prime \prime} \mathrm{W}$ & Bocagrande \\
& $10^{\circ} 24^{\prime} 03^{\prime \prime} \mathrm{N}$ & Bocagrande \\
$\mathbf{P}-4$ & $75^{\circ} 33^{\prime} 41.0^{\prime \prime} \mathrm{W}$ & \\
& $10^{\circ} 28^{\prime} 56.7^{\prime \prime} \mathrm{N}$ & Isla tierra Bomba \\
$\mathbf{P}-5$ & $75^{\circ} 33^{\prime} 04.8^{\prime \prime} \mathrm{W}$ & \\
\hline
\end{tabular}

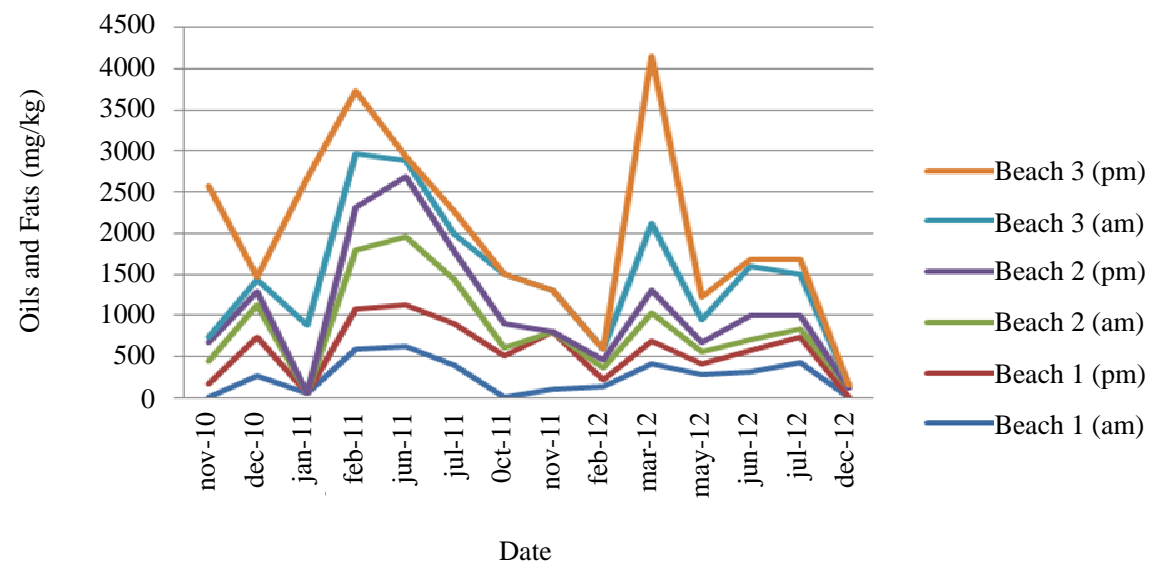

Figure 1. Presence of oils and fats in the sand on tourist beaches.

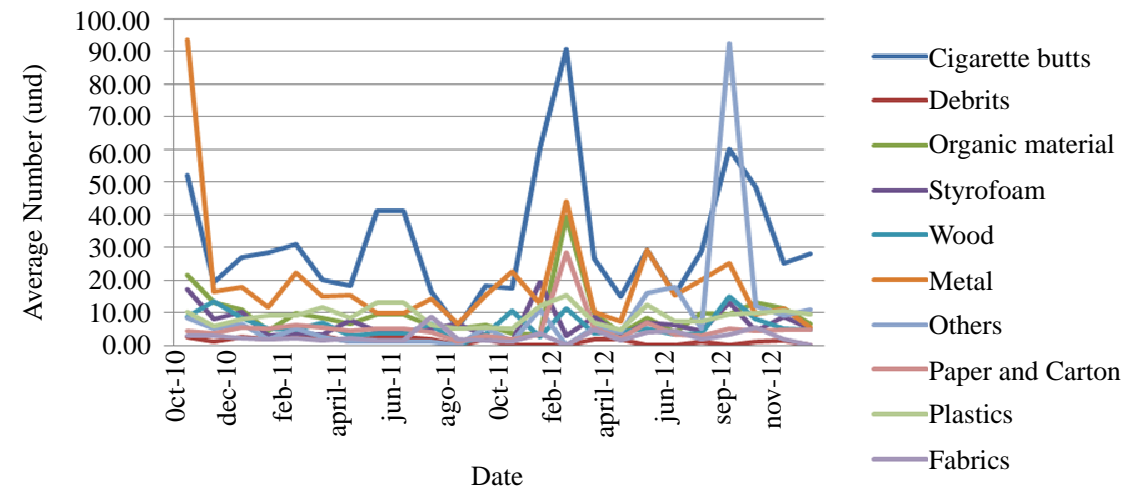

Figure 2. Average amount of waste per year. 
Considering three zones of occurrence of the residue, the area near the sea, tents and rest area and boardwalk area, according to Figure 3, there is a slight tendency for waste is most often prepared in the rest where the tents are located, the former is a condition of great importance on the quality of tourist beaches because it is an indicator of the generator or source of waste, which can be formulated management plans or management of beaches directed to solid waste management that integrates the guild of people that manage economic activities on the beaches to incline the conservation of environmental quality in them.

Figure 4 shows that there is significant variation in the frequency of occurrence of the residue with regard to time of day, i.e. the tendency of generation remains to be interchangeably morning, afternoon or evening. However the trend observed in appearance of the residue still shows cigarette butts and metals as waste predominant.

\section{Conclusions}

In the two beaches studied in Cartagena and the beach on the island of Tierra Bomba, there is presence of oils and fats in the sands, quantified values between 500 and 4500 $\mathrm{mg} / \mathrm{kg}$, these values are possibly attributed to the presence of motor boats circulating in the area.

In the presence of solid waste in the sand, the predominant waste cigarette butts and metals are found in beach sand with the highest incidence of occurrence in the area where the tents or rest area. The residues found affect environmental quality directly affecting the health quality indicators and landscape quality, considering also that the waste generated can reach the ocean and affect associated marine ecosystems.

The months with higher concentrations of waste are the months related to the tourist season, significantly increasing user density, however the trend generates

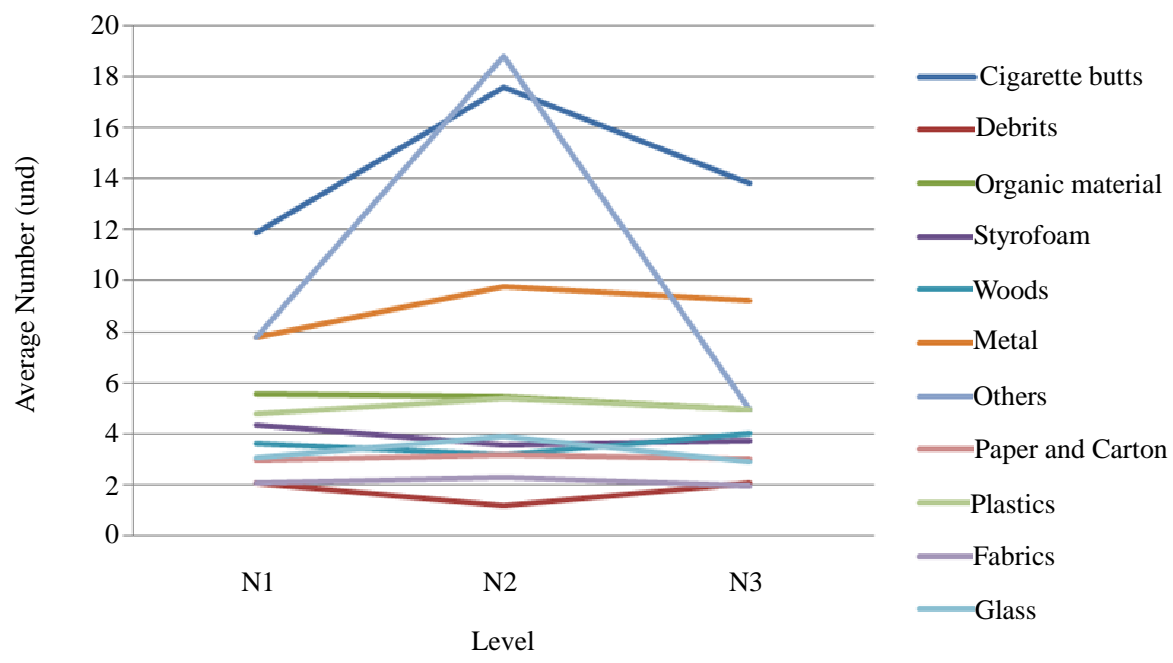

Figure 3. Average amount of waste in each level.

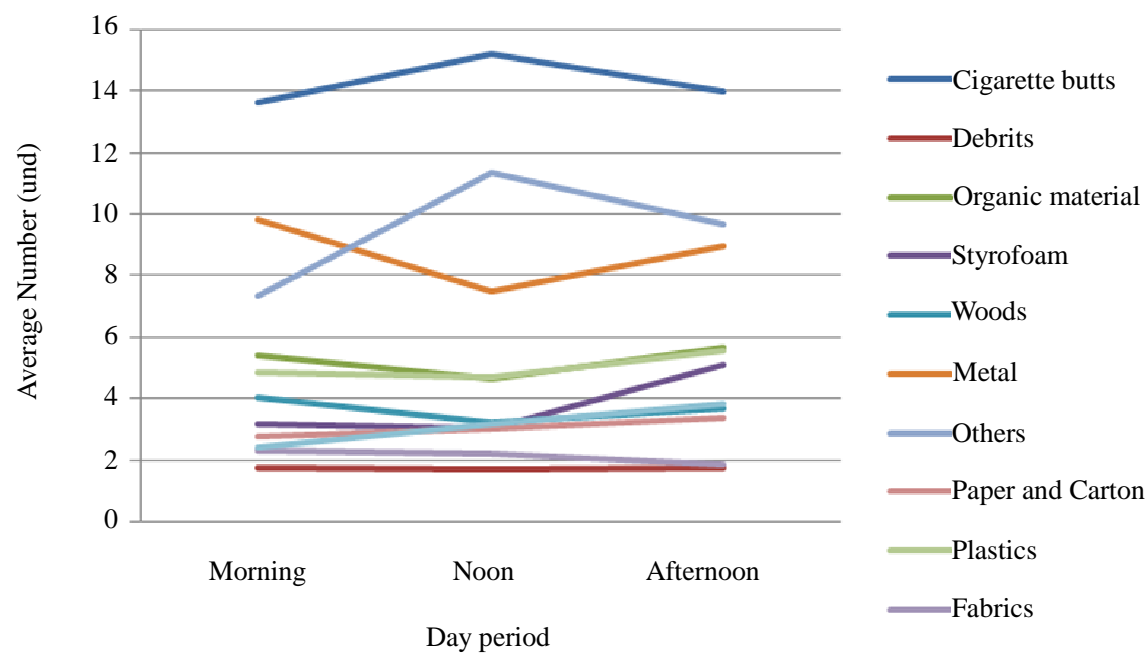

Figure 4. Average amount of waste according to time of day (morning-evening). 
no significant difference in the time of day in which the waste is generated.

\section{Acknowledgements}

The authors express their gratitude to Fundacion Universitaria Tecnologico Comfenalco (Comfenalco Technological University Foundation) for funding the project, the agency program ICAPTU, Environmental Quality Index Beaches Tours.

\section{REFERENCES}

[1] J. Buceta Miller, "Assessing the Quality of the Beaches, Civil Engineering,” No. 128, 2002, pp. 145-154. http://dialnet.unirioja.es/servlet/revista?codigo=708

[2] M. C. B. De Araujo and M. F. Costa, "Municipal Services on Tourist Beaches: Costs and Benefits of Solid Waste Collection,” Journal of Coastal Research, Vol. 22, No. 5, 2006, pp. 1070-1075.

[3] J. S. Silva, S. C. T. Barbosa and M. F. Costa, "Flag Items as a Tool for Monitoring Solid Wastes from Users on Urban Beaches,” Journal of Coastal Research, Vol. 24, No. 4, 2008, pp. 890-898.

[4] C. M. Botero and L. C. Garcia, "Quantification and Classification of Solid Waste in Tourist Beaches. Evaluation on Three Beaches of Santa Marta, Colombia,” 2011.

[5] S. Botero and R. L. Diaz, "The Beach and Coastal Area Particularly in Integrated Coastal Management, from the Literature Review,” 2009.

[6] G. Hurtado and S. C. Botero, "Selection and Parameters Proposed for the Determination of Environmental Quality in the Colombian Caribbean Tourist Beaches,” 2009.

[7] Ocean Conservancy, International Coastal Cleanup. 